Archaeology, has made an important contribution to African archaeology in the discovery of Tel Atrib and excavations in Alexandria. Recent work in Africa, connected with the researches on ancient cultures in the areas to be flooded on the construction of the Asswan Dam, include studies of the early Christian cathedral at Farras (eighth to eleventh centuries) with its unique collection of frescoes of unsurpassed historical and artistic value. African geographical studies have been concentrated at the Research Centre for Africa in the Geographical Institute of the University of Warsaw.

African studies are also undertaken at the Universities of Łódź, Toruń, Poznań, Wrocław, Cracow, and Lublin.

(Abridged from 'Polish Research Centres for African Studies', by Antoni Grzybowski, Przeglad Socjologiczny, xix. I, 1965, pp. 287-95)

\title{
Polish Sociological Review: Special Issue on Contemporary Africa
}

A SPECIAL number of the Polish Sociological Review (Przeglad Socjologiczny, tome xix. I, 1965 ), intended to sponsor discussion of African countries and cultures in the curriculum of Polish universities, has been devoted to papers on emerging Africa prepared by research workers of the Research Centre for African Studies, Polish Academy of Sciences, Warsaw. A paper by Mr. Mokpopo Dravi from Togoland, who studied at the University of Warsaw, is also included. The special number is offered as a contribution to the understanding of the formation of nationalities in contemporary Africa in the sense of Znaniecki's Modern Nationalities (1952). Relations between various systems of cultural values and antagonistic systems of political power are discussed and research is aimed at discovering forces working for harmonious co-operation.

\section{Educational Research in Mwanza}

A RESEARCH-TEAM of the Centre for the Study of Education in Changing Societies in Amsterdam is engaged in a study of the influence of education (mainly primary education) on the personality of the younger generation in the Mwanza district, i.e. in Mwanza town and a rural area some twelve miles to the south. The team consists of a geographer, a sociologist, an anthropologist, a psychologist, and an educationalist. The final report of the team is due to appear in 1969.

\section{(Communicated by Professor J. van Baal)}

\section{The West African Archaeological Newsletter}

Frve numbers of this newsletter have now been produced since its first appearance in December 1964. The first four numbers contain articles and reports of current excavations in West Africa by British and French archaeologists in English and French with summaries in the other language. As it is not on public sale the contents may not be quoted without the original author's permission. The fifth number (November 1966) is devoted to an account of the meeting of West African Archaeologists held at Fourah Bay in June I 966 (reported in Africa, xxxvi. 4, p. 442). It was agreed at this meeting that sufficient good material was now being produced in West Africa to warrant the creation of a professional archaeological journal, and a committee was set up. In the meantime the Newsletter is available for private circulation only and may be obtained from the Editor, Professor Thurstan Shaw, Institute of African Studies, University of Ibadan, Nigeria. 